\title{
SYNTHESIS AND CHARACTERIZATION OF ALGINATE-CARBOXYMETHIL CELLULOSE BEADS FROM CORN STALK (Zea mays) WITH CROSSLINK VARIATION $\mathrm{C}_{4} \mathrm{H}_{6} \mathrm{O}_{4} \mathrm{Zn}$
}

\author{
Annazmil Fayros Latifah ${ }^{1}$, Eny Yulianti ${ }^{*}$, Lilik Miftahul Khoiroh ${ }^{1}$ \\ ${ }^{1}$ Department of Chemistry, Faculty of Science and Technology, UIN Maulana Malik Ibrahim Malang Jalan \\ Gajayana 50, Malang 65144, East Java, Indonesia \\ ${ }^{2}$ Laboratory of Physical Chemistry, Department of Chemistry, Faculty of Science and Technology, UIN Maulana \\ Malik Ibrahim Malang, Jalan Gajayana 50, Malang 65144, East Java, Indonesia \\ *Corresponding author: enyyulianti@kim.uin-malang.ac.id
}

\begin{abstract}
Corn stalk has a high cellulose content, so that it is potential to be used as a composition for making alginate-carboxymethyl cellulose beads. Alginate and cellulose are biodegradable, renewable and non-meltable polymers that have wide applications in various industrial sectors. The purpose of this study was to determine the effect of crosslinking agent $\mathrm{C}_{4} \mathrm{H}_{6} \mathrm{O}_{4} \mathrm{Zn}$ on the adsorption and shape of beads. The varied concentrations of $\mathrm{C}_{4} \mathrm{H}_{6} \mathrm{O}_{4} \mathrm{Zn}$ are 3\%; 5\% and 10\%. Characterization of alginatecarboxymethyl cellulose beads composites using Fourier Transform InfraRed (FTIR), and Scanning Electron Microscope-Energy Dispersive X-Ray (SEM-EDX). Based on research, the highest swelling value is obtained at $5 \% \mathrm{C}_{4} \mathrm{H}_{6} \mathrm{O}_{4} \mathrm{Zn}$ crosslink which is $59.68 \%$. FTIR data shows the appearance of wave numbers at $1413 \mathrm{~cm}^{-1}$ which indicates the presence of $C-O \mathrm{Na}$ groups, while at wave number $458 \mathrm{~cm}^{-1}$ indicates the presence of $\mathrm{Zn}-\mathrm{O}$ groups. SEM-EDX data with a $5 \% \mathrm{C}_{4} \mathrm{H}_{6} \mathrm{O}_{4} \mathrm{Zn}$ crosslink has a round shape with a wrinkled surface, multiple grooves causing a non-homogeneous surface. Whereas in $\mathrm{C}_{4} \mathrm{H}_{6} \mathrm{O}_{4} \mathrm{Zn}$ $10 \%$ the surface is almost smooth.
\end{abstract}

Keywords: Alginate, Carboxymethil Cellulose, Corn Stalk

\section{INTRODUCTION}

Corn stalk waste contains $69 \%$ cellulose which has the ability to be an adsorbent, in natural and modified [1]. Carboxymethyl Cellulose (CMC) is a hydrophilic modification and can be processed into cellulose beads [2] while the process includes two steps, alkalization and carboxymethylation [3]. The purpose of alkalization is to activate hydroxyl groups on cellulose molecules and to be substituted by carboxymethyl with add sodium monochloroacetate [4].

The degree of substitution (DS) is substituted hydroxyl groups [5]. DS is a main factor in CMC solubility in solvents and has a commercial degree of substitution from 0.4 to 0.8 [6]. Adsorbent in the form of gel beads is more effective than powder, because in the form of powder there is a small hydrodynamic (water movement) barrier which causes it to dissolve easily [7]. 
Adsorption beads can be improved with making composite alginate beads. The optimal of sodium alginate / CMC composition for beads formation is $1: 2$ because it produces optimum swelling power [8]. The ionic gelation is a method used with the working principle of the dropping technique [9]. In the ionic gelation method the crosslink agent is used as a solution which is dripped with alginate-carboxymethyl cellulose to form a hydrogel [10].

Ions that can be used as crosslinking are $\mathrm{Ca}^{2+}, \mathrm{Zn}^{2+}$, and $\mathrm{Fe}^{3+}$ [11]. Zinc acetate $\left(\mathrm{C}_{4} \mathrm{H}_{6} \mathrm{O}_{4} \mathrm{Zn}\right)$ can produce a uniform size between beads and pores, because $\mathrm{Zn}^{2+}$ has stable and electronegative character [12] This is make the carboxylic acid $(\mathrm{COOH})$ of alginate ionized to $\mathrm{COO}^{-}$resulting in electrostatic repulsion that disturb the unity of beads by stretching the structure so that swelling power more maximum [13].

Beads with 3\% zinc acetate solution are flat and sticky. While beads with 5\% and $10 \%$ zinc acetate solution produce beads with round shape and harder not sticky [14]. However, cellulose alginate beads with crosslinks of $\mathrm{CaCl}_{2} 3 \%$ and $5 \%$ produce greater swelling power than the concentration of $10 \%$, with a percentage of 791, 651 and 276 [15]. This is because the higher crosslink concentration can induce the higher the crystallinity value, so the adsorption ability is lower.

Based on this background, it is necessary to develop research on the synthesis of CMC alginate beads from corn stalk with the addition of sodium alginate: CMC 1: 2 and variations concentration of crosslinks $\mathrm{C}_{4} \mathrm{H}_{6} \mathrm{O}_{4} \mathrm{Zn} 3 \%, 5 \%$ and $10 \%$ to obtain a rounded beads shape and optimal adsorption. The determination of $\mathrm{CMC}$ synthesis by the value of the degree of substitution and the determination of the best variation of crosslink concentration with swelling both gravimetrically and optical microscope. SEM-EDX to determine the morphology of beads and FTIR to determine the functional group.

\section{MATERIAL AND METHOD}

\section{Materials}

Corn Stalk waste obtained from Malang. The chemical used include sodium hydroxide $(\mathrm{NaOH})$ p.a (Merck), hydrochloric acid $(\mathrm{HCl})$ p.a (Merck), sodium monochloroacetate p.a, sodium chlorite $\left(\mathrm{NaClO}_{2}\right)$ p.a (Merck), sodium alginate $\left(\mathrm{C}_{6} \mathrm{H}_{7} \mathrm{O}_{6} \mathrm{Na}\right)_{n}$ p.a (Merck) and zinc acetate $\left(\mathrm{C}_{4} \mathrm{H}_{6} \mathrm{O}_{4} \mathrm{Zn}\right)$ p.a (Merck). 


\section{Extraction of Cellulose}

Corn stalks were cleaned and sun-dried, dry samples were crushed into powder with a size of 100 mesh, then put into oven for 24 hours at $90^{\circ} \mathrm{C}$. 50 grams of corn stalk powder were immersed in $1000 \mathrm{~mL} \mathrm{NaOH} 10 \%(\mathrm{w} / \mathrm{v})$ at $80^{\circ} \mathrm{C}$ for 90 minutes then washed several times with distilled water and squeezed. The pulp was treated with $200 \mathrm{~mL} \mathrm{NaClO} 21 \%$ (v/v) and added $\mathrm{CH}_{3} \mathrm{COOH} 10 \%(\mathrm{v} / \mathrm{v})$ to $\mathrm{pH} 5$ at $75^{\circ} \mathrm{C}$ for 1 hour. After that, it was washed with distilled water until the $\mathrm{pH}$ neutral and wrung. Cellulose pulp obtained was hydrolyzed with $5 \%(\mathrm{v} / \mathrm{v}) \mathrm{HCl}$ $(1: 20)$ at $95^{\circ} \mathrm{C}$ for 1 hour to obtain microfiber-dispersed [16]. The samples obtained were characterized by FTIR.

\section{Synthesis of Carboxymethil Cellulosa}

Five grams of corn stalk extract was added with $100 \mathrm{ml}$ of distilled water in a $250 \mathrm{ml}$ erlenmeyer. Then add $10 \mathrm{ml}$ of $30 \% \mathrm{NaOH}$ drops per drop for 1 hour. Then 6 grams of sodium monochloroacetate was added at a temperature of $60-70^{\circ} \mathrm{C}$. The mixture is soaked in residue using $100 \mathrm{~mL}$ of methanol for 24 hours. The resulting mixture was neutralized with glacial acetic acid, filtered and dried in an oven at $60^{\circ} \mathrm{C}$ until a constant weight was obtained [17] after which it was characterized using FTIR and the degree of substitution was determined.

\section{Variation of Crosslink $\mathrm{C}_{4} \mathrm{H}_{6} \mathrm{O}_{4} \mathrm{Zn}$}

One gram of sodium alginate is dissolved in $25 \mathrm{~mL}$ aqua demin. Then, carboxymethyl was added with an alginate-cellulose ratio of 1: 2 . Then the solution was dropped using an $18 \mathrm{G}$ syringe needle into $\mathrm{C}_{4} \mathrm{H}_{6} \mathrm{O}_{4} \mathrm{Zn} 3 \%, 5 \%$ and $10 \% 50 \mathrm{~mL}$ and allowed to stand for 24 hours. The formed beads are filtered and washed using aqua demin. BACMC is reacted in $50 \mathrm{~mL}$ of $10 \%$ $\mathrm{CH}_{3} \mathrm{COOH}$ and placed on a hotplate until bubbles do not appear. The resulting BACMC was washed to neutral $\mathrm{pH}$ with aquademin. The wet BACMC produced was dried using $37^{\circ} \mathrm{C}$ for 24 hours [16]

\section{Determination of the Degree of Substitution}

Two grams of carboxymethyl cellulose add $60 \mathrm{ml}$ of $95 \%$ ethanol solution and stirred. Then 10 $\mathrm{ml}$ of $2 \mathrm{M}$ nitric acid solution is added and the mixture is stirred again for 2 minutes. The mixture is heated for 5 minutes and stirred again for 15 minutes. After that, the mixture is filtered and the residue is washed using $30 \mathrm{ml}$ of $95 \%$ ethanol solution which has been heated to $60^{\circ} \mathrm{C}$. The residue is then washed again using a methanol solution, and followed by drying in an oven at

\section{J. Islamic Pharm., an open access journal}

ISSN: 2527-6123 
$105 \mathrm{oC}$ for up to 3 hours. $0.5 \mathrm{~g}$ of residue is put in Erlenmeyer then $100 \mathrm{ml}$ of distilled water is added while stirring. After that, add $25 \mathrm{ml}$ of $0.5 \mathrm{~N} \mathrm{NaOH}$ solution, and heat for 15 minutes. In hot conditions, the mixture is titrated with $0.3 \mathrm{~N} \mathrm{HCl}$ solution and using the pp indicator.

\section{Characterization of Functional Groups}

The measurement is performed using Bruker-Alpha. The sample of $5 \mathrm{mg}$ is pressed into a disk for FTIR measurement.

\section{Swelling Beads}

A total of $\pm 40 \mathrm{mg}$ alginate beads: CMC is immersed in $10 \mathrm{~mL}$ aqua demineralization. BACMC was weighed after being soaked for 3, 5, 8, 24, 29 and 31 hours. Gravimetric swelling test is determined based on (Equation 3.1) and optical microscopy is processed using the Image-J based application (Equation 3.2) both before and after swelling.

$$
\begin{aligned}
& \% \text { Swelling }=\frac{W t-W o}{W o} \times 100 \% \\
& \text { Diameter }(\mathrm{D})=\sqrt{((\mathrm{LA} \times 4) / 3,14)}
\end{aligned}
$$

where, $\mathrm{W}_{0}$ and $\mathrm{W}_{\mathrm{t}}$ are the masses of the dry and swollen beads, respectively, at a time $(t)$.

\section{Characterization of Surface Morphology}

Surface morphology characterization with SEM-EDX was carried out at 40x and 5.000x.

\section{Activity as adsorbent for Methylene Blue}

About $5 \mathrm{mg}$ of methylene blue was dissolved into $100 \mathrm{~mL}$ of distilled water, then pipetted $10 \mathrm{~mL}$ and placed into a test tube based on variations in crosslink concentration. Then, as many as 3 beads based on variations of crosslinks were placed into a blue methylene solution and absorbance was measured using UV-Vis at $664 \mathrm{~nm}$ [18]. The beads activity test was carried out for 168 hours [12] by observing the decrease in absorbance of the beads for each variation of crosslink concentration. The determination of adsorption capacity is based on (Equation 3.3).

$$
\mathrm{q}_{\mathrm{t}}=\frac{\mathrm{Co}-\mathrm{Ct}}{m} \times \mathrm{V}
$$

\section{RESULT AND DISCUSSION}

\section{Extraction of Cellulose}

In this process $\mathrm{NaOH}$ base compounds are used and a cellulose extract yield of $93.5 \%$ with a moisture content of $6.3 \%$ is obtained, the yield indicates the value of the extract produced 
a lot. After delignification, the particles turn blackish brown, which indicates that lignin is still present. Then the next stage is soaking using sodium chlorite $\left(\mathrm{NaClO}_{2}\right)$ to whiten the remaining lignin remaining. According to [19], sodium chlorite is a powerful oxidizer that can degrade lignin without damaging cellulose.

\section{Synthesis of Carboxymethil Cellulosa}

CMC synthesis process include two main stages, alkalization and carboxymethylation. Alkalization is carried out to develop cellulose structure so as to facilitate the substitution of carboxylation reagents into cellulose structure. The carboxymethylation is carried out to substitute the anhydroxyl group in the anhydroglucose unit using a carboxymethylation reagent

Table 1 is a DS result of 0.7264 if 5 grams of NaMCA is added, while the addition of 6 grams of NaMCA produces a DS of 0.604 . The amount of sodium monochloroacetate used affects the substitution of the anhydroglucose unit in cellulose. According to [20], the amount of alkali used can increase the amount of dissolved monochloroacetic salt, making it easier and accelerating the diffusion of monochloroacetic salt into the hydroxy group. However, according to [21], the purity of CMC will decrease if more NaMCAs are added, this is due to the formation of $\mathrm{NaCl}$ by products and a decrease in the degree of substitution.

Based on research conducted by [22] an increase in the value of DS to 0.7 can increase the value of swelling by $144.6 \%$. Addition of carboxymethyl groups in cellulose expressed as the degree of substitution can change the nature of cellulose which was originally hydrophilic to hydrophobic, there by reducing the level of carboxymethyl cellulose solubility in water.

From Figure 2, a graph sample spectra of cornstalk powder, delignification, bleaching, cellulose after hydrolysis and CMC were obtained. In the IR spectra of cornstarch powder there was a peak in the region of $3409 \mathrm{~cm}^{-1}$ which showed strain $\mathrm{O}-\mathrm{H}$ bonds and in the area of 2920 $\mathrm{cm}^{-1}$ showed the strain of $\mathrm{C}-\mathrm{H}$ saturated bonds in cellulose and hemicellulose. The $\mathrm{C}=\mathrm{O}$ ester bond in hemicellulose is shown in the region of $1733 \mathrm{~cm}^{-1}$ whereas the $\mathrm{C}=\mathrm{O}$ carboxylic bond that is in cellulose, lignin and hemicellulose is shown in the region $1634 \mathrm{~cm}^{-1} .1513 \mathrm{~cm}^{-1}$ and $1457 \mathrm{~cm}^{-1}$ indicate aromatic $\mathrm{C}=\mathrm{C}$ compounds in lignin. The C-O-C (aryl-alkyl ether) bond appears in the $1250 \mathrm{~cm}^{-1}$ region, where this region indicates the presence of lignin polymers due to ether bonds [23]. 
The IR cellulose spectra with CMC there are wave numbers in the area of $3436 \mathrm{~cm}-1$ which shows the presence of $\mathrm{OH}$ groups and is a characteristic of cellulose. According to [24], $\mathrm{OH}$ functional groups are very strong at wave number $3427 \mathrm{~cm}-1$. In CMC IR spectra there is a wave number of $1596 \mathrm{~cm}-1$ indicating the presence of a carboxyl group (COO-) and a wave number of $1413 \mathrm{~cm}-1$ indicating the presence of a carboxyl group as a salt. According to [25], CMC was identified to have a carboxyl group in the area of $1600 \mathrm{~cm}-1$ and according to [26] the presence of a carboxyl group as a salt was shown in an area of around $1423 \mathrm{~cm}-1$. In the area of $1334 \mathrm{~cm}-$ 1 and $1063 \mathrm{~cm}-1$ each showed the -OH and ether bonds, namely the C-O-C group. According to [25], the ether group (-O-) in the area of $1068 \mathrm{~cm}-1$. From the results of the functional groups measured in the IR spectrum with each absorption at a certain wavelength region shows conformity to the carboxymethyl cellulose structure. This is indicated by the vibration of -OH, the carboxyl group (COO-), and the ether group (-O-).

\section{Swelling Power, Optical Microscope Measurement Diameter and Beads Mechanical Strength.}

The difference in the concentration of zinc acetate solution 3\%,5\%, and $10 \%$ affects the shape of the beads produced. Beads made with 3\% zinc acetate solution are slightly flat, not round with jagged and caudal edges, while beads made with 5\% and $10 \%$ zinc acetate solution produce round shapes with more regular edges. The physical differences of the three crosslink concentrations used are shown in Figure 3

Of the three different crosslink concentrations above, beads with a harder texture are produced by the highest concentration of 10\%, as tested by the hardness test shown in Figure 4. This is because the more the amount of zinc ions that bind to alginates, the greater the cross links that are formed and the resulting beads are getting rounder and harder [14]. According to [27], the higher concentration of crosslinkers can increase the value of crystallinity. So that the stiffness of beads is also increasing [28].

Between concentrations of 5\% and $10 \%$ produce a difference of hardness of $0.98 \mathrm{Kgf}$. Meanwhile, based on research conducted by [32], an increase in $\mathrm{CaCl} 2$ crosslink concentration by $5 \%$ can increase the hardness of beads formed by a difference of $0.6 \mathrm{~kg}$. This is because the affinity between COO- with $\mathrm{Zn}^{2+}$ ions is greater than with $\mathrm{Ca}^{2+}$ ions [33]. 
The ability of beads to expand was observed in aquademin media at room temperature for several hours and repeated three times (triplo). The difference in immersion time (5, 24, 29 and 31 hours) results in a different maximum swelling value, where the concentration of 3\% at 29 hours, while the concentration of 5\% and $10 \%$ at 24 hours. From the variation of concentration and immersion obtained maximum swelling power data produced by a concentration of 5\% with a value of $59.68 \%$ while a minimum swelling power produced by a concentration of $10 \%$ with a value of $35.7 \%$. The highest swelling value shows that the conversion of polymer into the gel matrix has been optimum [28]. After passing the optimum time, the matrix beads are diffused causing swelling to decrease. Diffusion occurs when the entrained substance flows through the pores of the polymer or through the space between the polymer chains, as shown in Figure 5.

In this study, the decrease in swelling power along with the increase in concentration in accordance with research conducted by [27], where with increasing crosslink concentration, the number of $\mathrm{Zn}^{2+}$ ions in liquid volume units will increase and more $\mathrm{Zn}^{2+}$ ions bound to the sodium alginate chain. This results in less space so less water can get into the beads. On the other hand, the number of COO-ion groups will decrease because there is a bond between the $\mathrm{Zn}^{2+}$ and $\mathrm{COOH}$ ions present in sodium alginate. Thus, the electrostatic repulsion between $\mathrm{COO}^{-}$ions becomes weak and causes a decrease in the swelling power of the beads.

Based on research conducted by [29], making beads with variations in the concentration of zinc acetate $1 \%, 2.5 \%, 5 \%$ and $10 \%$ produces an optimal concentration of $5 \%$ for the next optimization process. This is because if the lowest concentration of $1 \%$ produces the highest swelling power, it is followed by rapid erosion of the beads. Whereas if the highest concentration of $10 \%$ results in the lowest swelling power, the strength of the high cross-linking causes aggregation.

The diameter after immersion increases with the weight of the beads and begins to shrink when it reaches maximum swelling. According to [14], this is caused by the occurrence of syneresis on beads which causes fluid in the beads to come out and evaporate, so the diameter size also shrinks. The percent diameter chart results are shown in Figure 6

In Figure the emergence of new uptake at the addition of zinc acetate concentrations of $3 \%, 5 \%$ and $10 \%$ in the wave numbers 458 and $460 \mathrm{~cm}-1$ indicates the presence of $\mathrm{Zn}-\mathrm{O}$ groups. Based on research conducted by [30], the presence of $\mathrm{ZnO}$ in the photocatalyst results of 
synthesis is shown by the presence of a sharp characteristic peak at the wave number $468.24 \mathrm{~cm}$ 1. According to [31], the peak of $\mathrm{Zn}-\mathrm{O}$ vibrational uptake was shown at wave number 590-400 $\mathrm{cm}-1$, so that the appearance of uptake in the area of 458 and $460 \mathrm{~cm}-1$ indicated the existence of cross links on beads. However, there is a difference in absorption at variations in concentration of $3 \%, 5 \%$ and $10 \%$, where the peak characteristic concentration is $10 \%$ sharper and wider than other variations, this is because the greater the concentration the sharper peak produced.

\section{SEM-EDX analysis}

Beads morphology were analyzed by SEM-EDX (Scanning Electron Microscope Energy Dispersive X-Ray Spectroscopy) to analyze the material components both quantitatively and qualitatively. Morphology of zinc alginate gels formed at concentrations of 5\% and 10\% is shown in Figure 8.

In the picture above it can be seen that the zinc alginate gel formed at a concentration of $5 \%$ has a round shape with a wrinkled surface, multiple grooves that prove the surface is not homogeneous. Whereas at a concentration of $10 \%$, visible wrinkles disappear and the surface is almost smooth. According to [34], an increase in crosslink concentration causes crosslinking to increase and make the gel stronger so that it can produce a homogeneous surface.

Based on the EDX in table 2 results above, obtained elements contained in BACMC with $5 \%$ zinc acetate concentration are elements $\mathrm{C}, \mathrm{O}, \mathrm{Zn}, \mathrm{Na}$ and $\mathrm{Cl}$, with $\mathrm{Zn}$ content of 3.9. Whereas at a concentration of $10 \%$, it was found that $\mathrm{Zn}$ content was higher than before, which was $7.5 \%$. This indicates that the higher the crosslink concentration, the $\mathrm{Zn}^{2+}$ cation ion contained in the beads is getting bigger, but at a concentration of $10 \%$ there is no $\mathrm{Cl}$ element. Based on research conducted by [35], the presence of salt $(\mathrm{NaCl})$ can cause a higher swelling power value than if there is no salt. According to [36], the swelling of polymers in the presence of salt is due to the osmotic swelling process, which is the pressure on ionic contributions.

\section{Beads Activity as adsorbent Methylene}

Figure 9 shows the results of the bead activity test graph on adsorption of methylene blue. The Activity Test was studied by soaking beads with varying concentration in duplicate over several days. The absorption capacity of the three beads increased sharply on the 7th day to the 16th day, then increased more slowly on the 22nd day and decreased on the 28th day. This shows the optimum time to absorb methylene blue is on the 22nd day.

\section{J. Islamic Pharm., an open access journal}

ISSN: 2527-6123 
From the three variations of beads concentration, the most data that absorbs methylene blue is $3 \%$ concentration which is $42.75 \mathrm{ppm}$. However, concentrations of 5\% and $10 \%$ also absorb the maximum with a difference not far from 5\% which is only 1.45 and $4.32 \mathrm{ppm}$. This is because according to [37], hydrogels with a porous tissue structure, high surface area, and lots of phenolic hydroxyl are proven to be effective adsorbents for removing methylene blue dyes from aqueous solutions.

\section{CONCLUSION}

Variation in crosslink concentration on beads affects the shape and mechanical strength (hardness), where the higher the concentration, the more round and harder the beads. This variation also affects the swelling power and the increase in diameter of beads, where the higher the concentration, the swelling power and the increase in diameter are smaller. However, the maximum swelling power is produced by a concentration of $5 \%$, which is equal to $59.68 \%$. Based on FTIR analysis, the carboxymethyl cellulose character produces a new absorption at the wave number $1418 \mathrm{~cm}^{-1}$ which indicates the presence of C-ONa groups. Whereas the addition of $\mathrm{C}_{4} \mathrm{H}_{6} \mathrm{O}_{4} \mathrm{Zn}$ crosslink variations resulted in new absorption at 458 and $460 \mathrm{~cm}^{-1}$ which indicated the presence of $\mathrm{Zn}-\mathrm{O}$ cross links. Character of carboxymethyl cellulose alginate beads with a crosslink concentration of $10 \%$ based on SEM-EDX analysis has a finer surface shape than a concentration of $5 \%$.

\section{REFERENCES}

[1] Suhas, Gupta, V.K., Carrott, P.J.M., Singh, R., Chaudhary, M., dan Kushwaha, S. 2016. Cellulose: A Review as Natural, Modified and Activated Carbon Adsorbent. Bioresource Technology, 216: 1066-1076.

[2] Swatloski, R., Holbrey, J., Spear, S., dan Rogers, R. 2002. Ionic Liquids for the Dissolution and Regeneration of Cellulose. Conference Paper, 155-164.

[3] Lou, Z., Zhao, Z., Li, Y., Shan, W., Xiong, Y., Fang, D., Yue, S., dan Zang, S. 2013. Contribution of Tertiary Amino Groups to Re(VII) Biosorption on Modified Corn Stalk: Competitiveness and Regularity. Bioresource Technology, 133: 546-554.

[4] Bidin, A. 2010. Optimasi Kondisi Reaksi Sintesis Karboksimetil Selulosa Dari Jerami Padi (Oryza sativa). Skripsi. Palu: Universitas Tadulako.

[5] Wijayani A., U. Khoirul, T. Siti. 2005. Karakterisasi Karboksimetil Selulosa (CMC) dari Eceng Gondok (Eichornia crassipes (Mart) Solms). Indo. J. Chem. 5 (3): 228 - 231. 
[6] (Waring and Parsons, 2001). Physico Chemical Characterization of Carboxymethylated spun cellulose fibres. Article in Biomaterials. Vol 22 (9) : 903

[7] Radna, 2010. Immobilization of Humic Acid on Chitosan Beads by Protected Crosslinking Method and Its Application As Sorbent For Pb (II). Journal of Chemistry. Vol 10, No 1.

[8] Bajpai, S.K. dan Shubhra Sharma. 2004. Investigation of swelling/degradation behaviour of alginate beads crosslinked with $\mathrm{Ca}^{2+}$ and $\mathrm{Ba}^{2+}$ ions. Reactive \& Functional Polymers, $59,129-140$.

[9] Sayeda et al (2013). Preparation and characterization of crosslinked alginate-CMC beads for controlled release of nitrate salt. Journal of Radioanalytical and nuclear chemistry. ISSN 0236-5731.

[10] Agarwal et al (2013). Calcium alginate-carboxymethyl cellulose beads for colon-targeted drug delivery. International Journal of Biological Macromolecules 75 (2015) 409-417

[11] Kim, et al. 2009. Adsorption of Zinc and Toluene by Alginate Complex Impregnated with Zeolite and Activated Carbon. Curr Appl Phys. 9. 694-697.

[12] Sonmez, et al. 2016. Alginate/Cellulose Composite Beads for Environmental Applications. U.P.B. Sci. Bull. Series B, Vol. 78, Iss. 2.

[13] Supramaniam, J., Adnan, R., Mohd Kaus, N.H., dan Bushra, R. 2018. Magnetic Nanocellulose Alginate Hydrogel Beads as Potential Drug Delivery System. International Journal of Biological Macromolecules, 118: 640-648.

[14] Ayuningtyas, F., 2012, Pembuatan dan Karakterisasi Beads Hidrogel dari Berbagai Polimer sebagai Media Tanam. Skripsi. Jurusan Farmasi Fakultas MIPA Universitas Indonesia

[15] Sayeda et al (2013). Preparation and characterization of crosslinked alginate-CMC beads for controlled release of nitrate salt. Journal of Radioanalytical and nuclear chemistry. ISSN 0236-5731.

[16] Suvachittanont, S dan Pookingdao, W. 2013. Development of Porous Spherical Cellulose Beads Production from Corn Cob as an Exfoliating Agent for Cosmetic Industries. Journal of Chemistry and Chemical Engineering. 7(12): 1156-1163.

[17] Melisa, M., Bahri, S., \& Nurhaeni, N. (2014). Optimasi Sintesis Karboksimetil Selulosa Dari Tongkol Jagung Manis (Zea Mays L Saccharata). Natural Science: Journal of Science and Technology, 3(2)

[18] Nisa D., W.D.K. Putri. 2014. Pemanfaatan Selulosa dari Kulit Buah Kakao (Teobroma cacao L.) sebagai Bahan Baku Pembuatan CMC (Carboxhymethyl cellulose). Jurnal Pangan dan Agroindustri. 2 (3): 3442.

[19] D.-q. Li, J. Wang, Z.-g. Guo, J. Li, J. Shuai, Pectin gels cross-linked by Ca2+: An efficient material for methylene blue removal, J. Mol. Liq. 238 (2017) 36-42.

[20] Nur'ain, dkk. 2017. Optimasi Kondisi Reaksi untuk Sintesis Karboksimetil Selulosa (CMC) dari Batang Jagung (Zea mays L.). Palu : Universitas Tadoluko

[21] Wijayani, A., Ummah, K. dan Tjahjani, S. (2005). Karakterisasi karboksimetil selulosa (CMC) dari enceng gondok (Eichornia crassipes (Mart) Solms). Indonesian Journal of Chemistry 3: 228-231.

[22] Yuliasih and Sunarti, 2014. Pati Sagu Termodifikasi sebagai Bahan Starch-Based Plastics. Prosiding Seminar Nasional Kulit, Karet dan Plastik. 
[23] Putera, R.D.H. 2012. Ekstraksi Serat Selulosa dari Tanaman Eceng Gondok (Eichornia Crassipes) dengan Variasi Pelarut. Skripsi. Depok: Fakultas Teknik UI.

[24] Erningsih 2011. Producing Of CMC From Corn Cobs Waste For Thickener Of Textile Printing Process. Volume 26 No.2 - Desember 2011 : 61-120106

[25] Safitri et al 2017. Sintesis Karboksimetil Selulosa (CMC) dari Selulosa Kulit Durian. Kovalen, 3(1): 58-68

[26] Mondal 2015. Preparation of food grade CMC from corn husk agrowaste. International journal of biological macromolecule

[27] Ibrahim et al 2013. Preparation and characterization of crosslinked alginate-CMC beads for controlled release of nitrate salt. Journal of radioanalytical and nuclear chemistry

[28] Puspitasari, Sindi. 2017. Preparasi dan Karakterisasi Komposit Beads Alginat-Selulosa dari Ampas Tebu Melalui Metode Gelasi Ionik dengan CaCO3 Sebagai Porogen. Skripsi. Malang: UIN Maulana Malik Ibrahim Malang.

[29] Das, et al 2010. Corn Starch Plasticized With Isosorbide. Carbohydrat Polymers. Vol 206.

[30] Amri and Utomo 2017. Preparasi dan Karakterisasi Komposit Zn-O Zeolit untuk Fotodegradasi Zat Warna Congo Red. Jurnal Kimia Dasar. Vol 6 No 2

[31] Akbari et al. 2016. PH-sensitive bionanocomposite hydrogel beads based on carboxymethil cellulose/Zn-O nanoparticle as drug career. International journal of Biological Macromolecule

[32] Rajmohan and Bellmer 2019. Characterization of Spirulina-Alginate Beads Formed Using Ionic Gelation. International Journal of Food Science

[33] Verma and Pandit, 2012. Floating Gellan-Chitosan Polyelectrolyte Complex Beads: Effect of Gelucires Incorporation on Encapsulation Efficiency and Drug Release. Journal Of Pharmacy. 31(1):37-42

[34] Haldar, et al. 2018. Effect of Liquid Pool Concentration on Chemically Reactive Drop Impact Gelation Process. Journal of Colloid and Interface Science. 528: 156-165.

[35] Hidayah 2018. Sintesis dan Karakterisasi Beads Alginat Selulosa Xantat dari Batang Jagung dengan Variasi Porogen NaCl. Skripsi. Malang: UIN Maulana Malik Ibrahim Malang.

[36] Horkay et al. 2000. Osmotic Swelling of Polyacrylate Hydrogels in Physiological Salt Solutions. Biomacromolecules, Vol. 1, No. 1, 2000.

[37] Moghaddam et al 2019. Synthesis of new hydrogels based on pectin by electron beam irradiation with and without surface modification for methylen blue removal. Manuscript 


\section{J. Islamic Pharm. 2019. 4(1): 40-55}

Table 1. Degree of Substitution (DS)

\begin{tabular}{|c|c|}
\hline NaMCA: Cellulosa & DS \\
\hline $5: 5$ & 0,726 \\
\hline $6: 5$ & 0,604 \\
\hline
\end{tabular}

Table 2. Percent weight of each element of BACMC with varying concentrations of zinc acetate $5 \%$ and $10 \%$

\begin{tabular}{|l|c|c|c|c|c|}
\hline \multirow{2}{*}{ Sample } & \multicolumn{5}{|c|}{ Percent weight of each element (\%) } \\
\cline { 2 - 6 } & $\mathbf{C}$ & $\mathbf{O}$ & $\mathbf{Z n}$ & Na & Cl \\
\hline $\mathrm{C}_{4} \mathrm{H}_{6} \mathrm{O}_{4} \mathrm{Zn} 5 \%$ & 50 & 44.42 & 3.9 & 1.46 & 0.22 \\
\hline $\mathrm{C}_{4} \mathrm{H}_{6} \mathrm{O}_{4} \mathrm{Zn} 10 \%$ & 49.65 & 40.75 & 7.5 & 2.1 & - \\
\hline
\end{tabular}

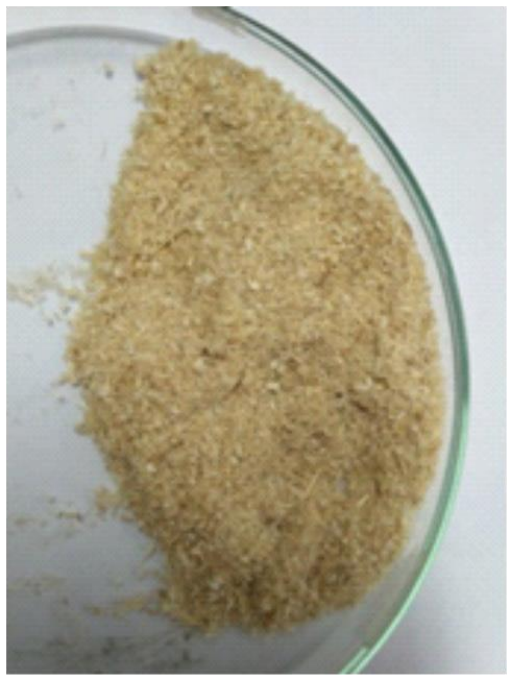

(a)

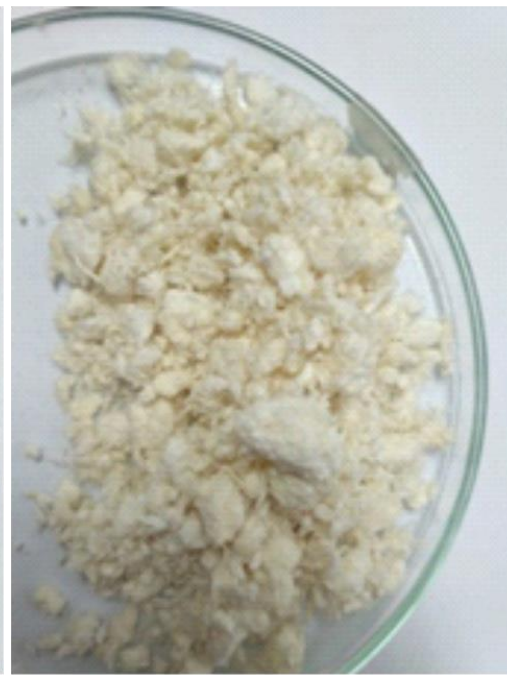

(b)

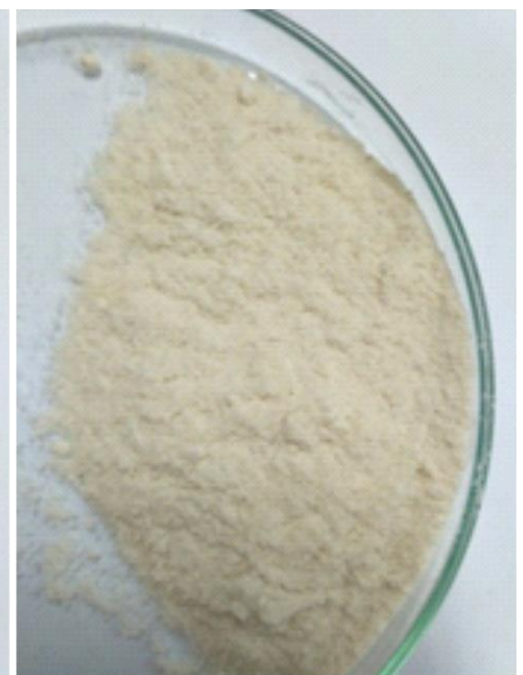

( c)

Figure 1. a) Corn stalk powder b) Cellulose extract c) CMC 


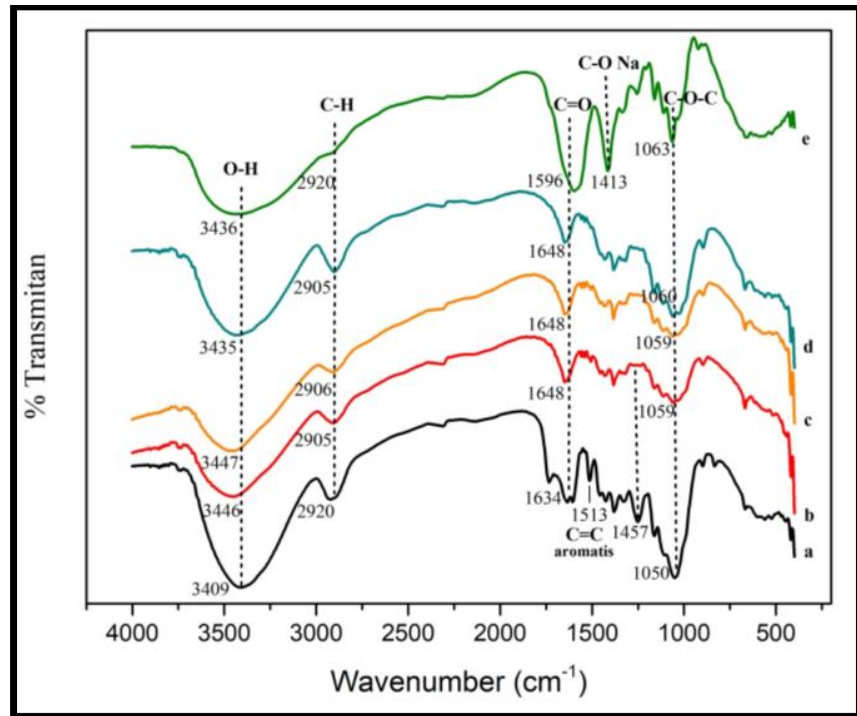

Figure 2. IR spectra (a) corn stalk powder, (b) delignification, (c) bleaching, (d) extraction of cellulose, and (e) CMC
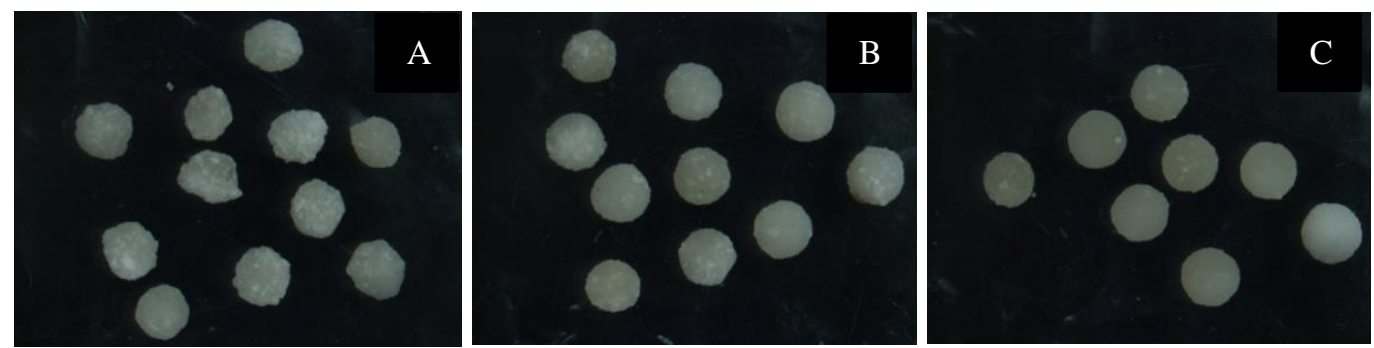

Figure 3. Physical differences in beads with concentrations of 3\%, 5\%, and $10 \%$.

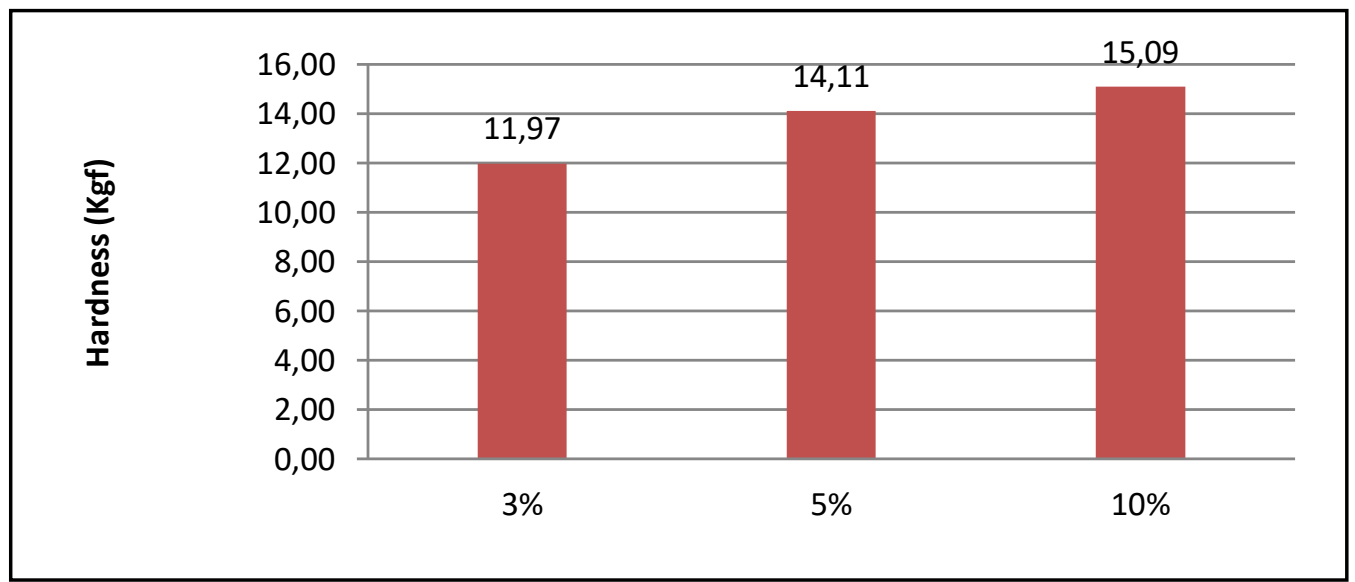

Figure 4. Hardness Test Results from 3 variations of crosslink concentrations 


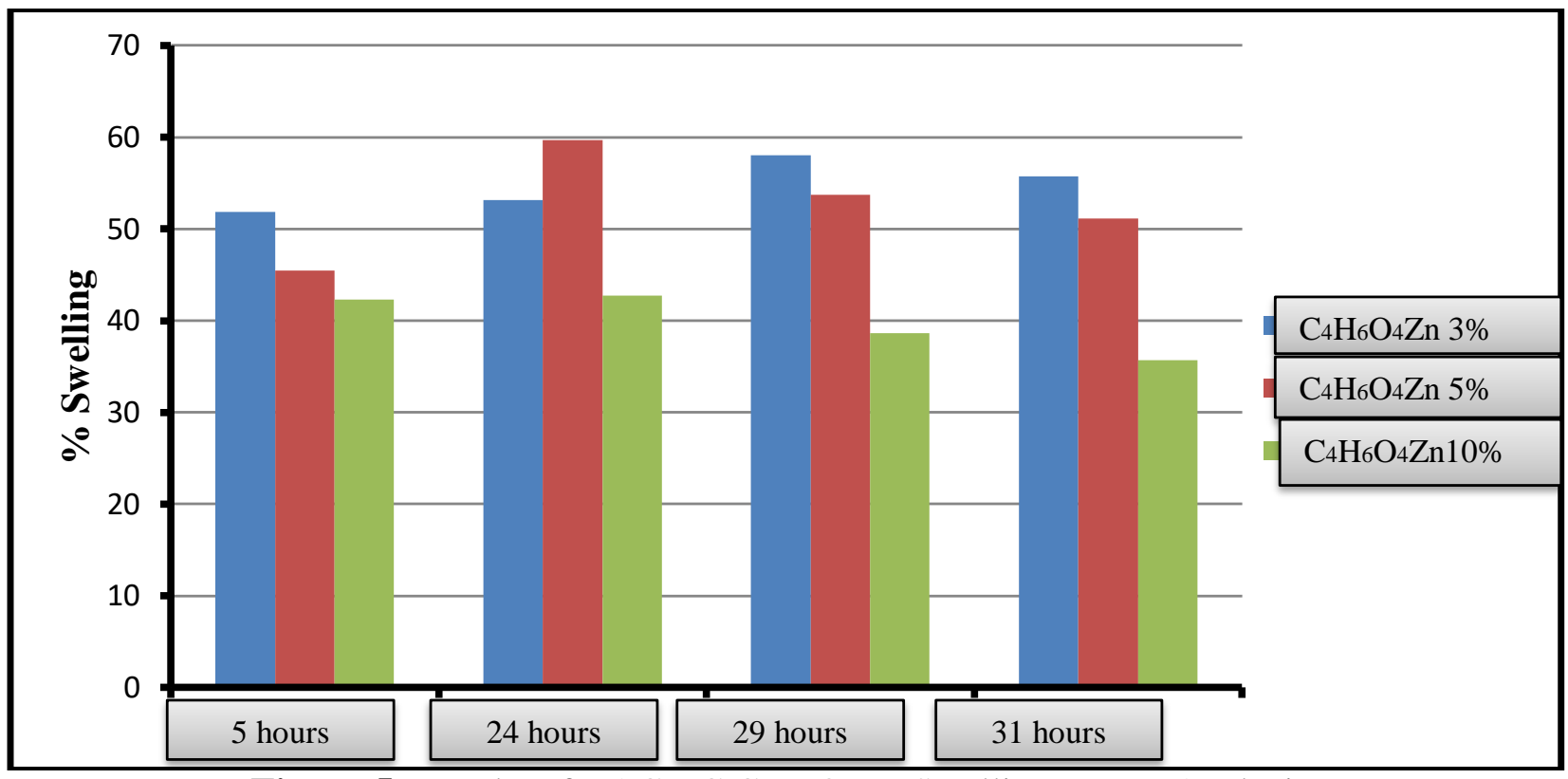

Figure 5. Results of BACMC $\mathrm{C}_{4} \mathrm{H}_{6} \mathrm{O}_{4} \mathrm{Zn}$ Swelling Power Analysis

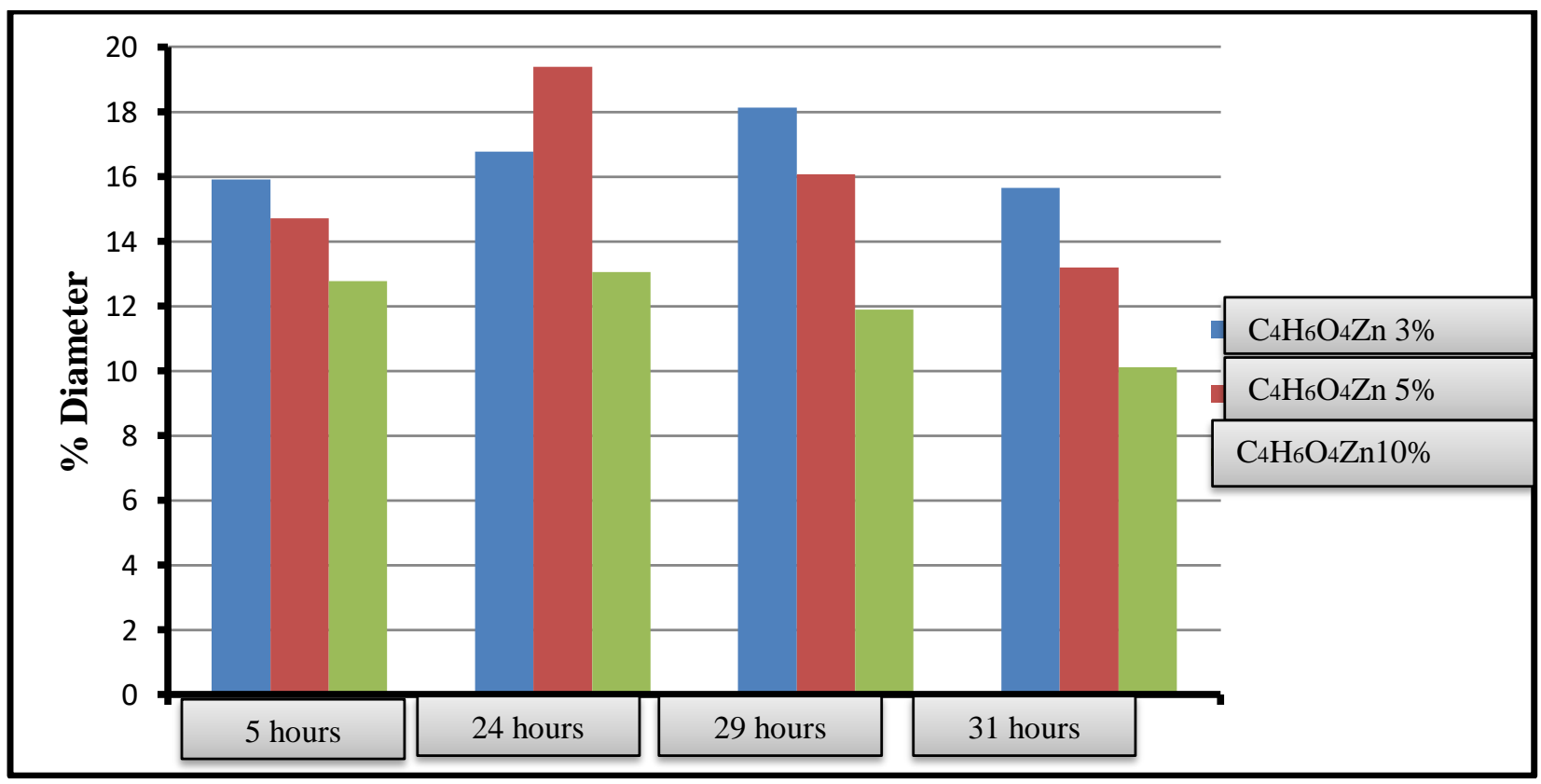

Figure 6. Graph of average beads diameter 


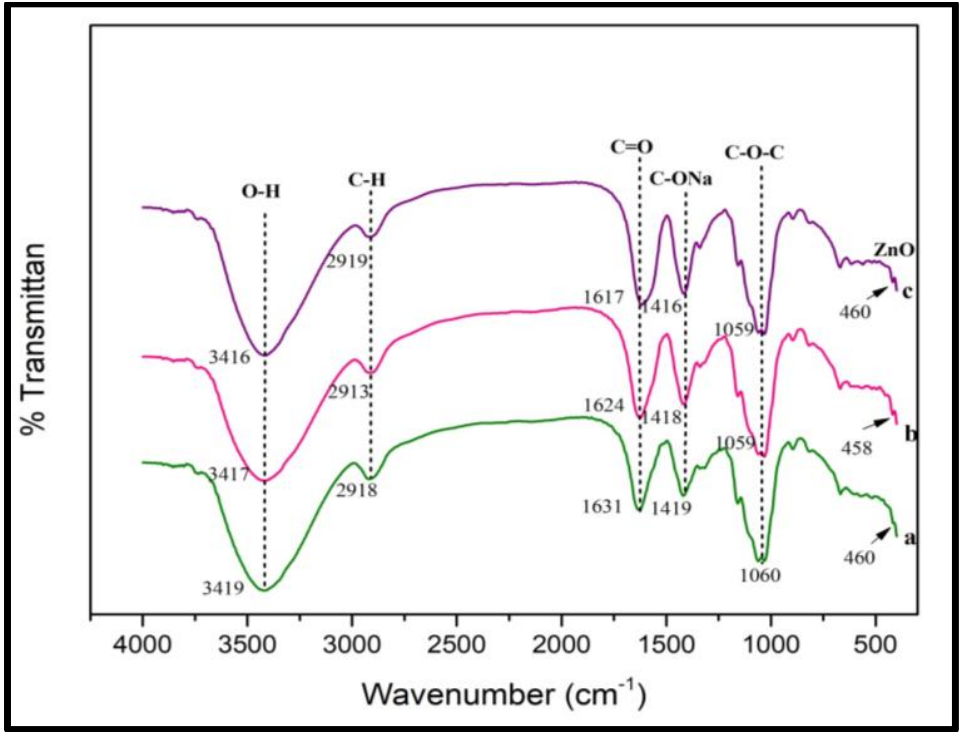

Figure 7. IR Spectra of crosslink Zn (a) 3\%, (b) 5\%, and (c) 10\%

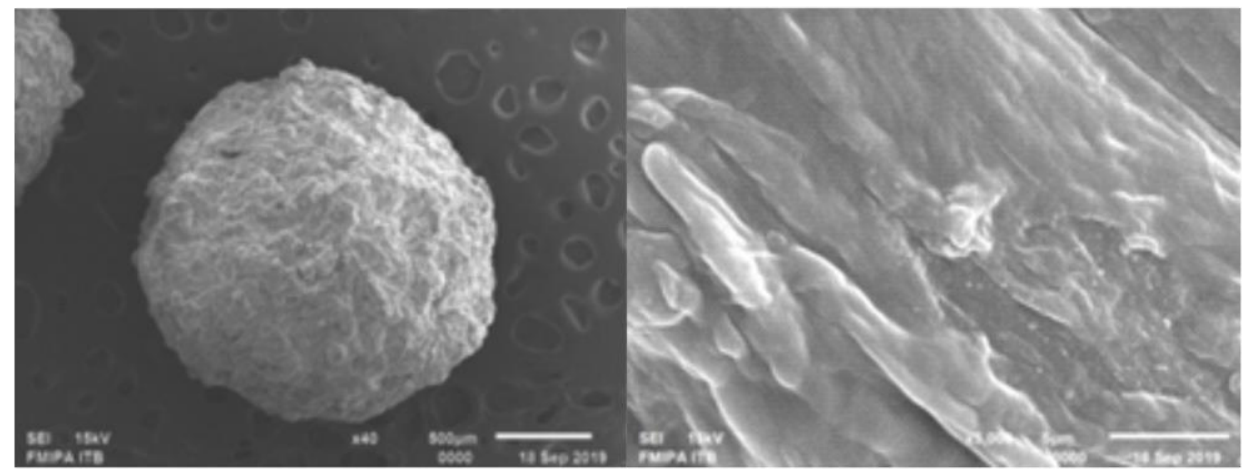

(a)

(b)

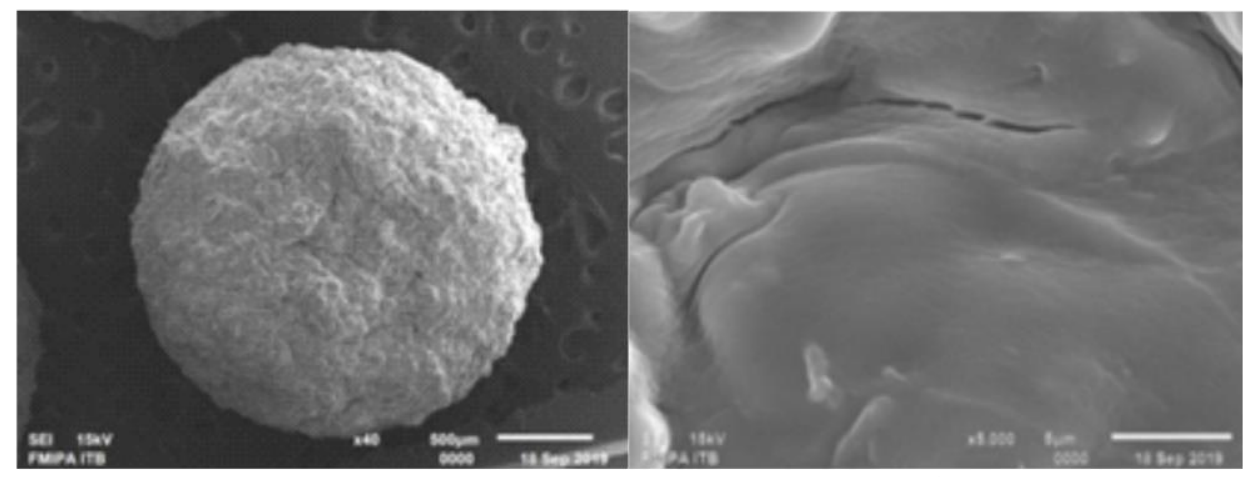

(c)

(d)

Figure 8. SEM characterization results (a) $\mathrm{BACMC} \mathrm{C}_{4} \mathrm{H}_{6} \mathrm{O}_{4} \mathrm{Zn} 5 \%$ magnification 40x (b) 5000x magnification (c) BACMC C ${ }_{4} \mathrm{H}_{6} \mathrm{O}_{4} \mathrm{Zn} 10 \%$ 40x magnification and (d) 5000x magnification. 


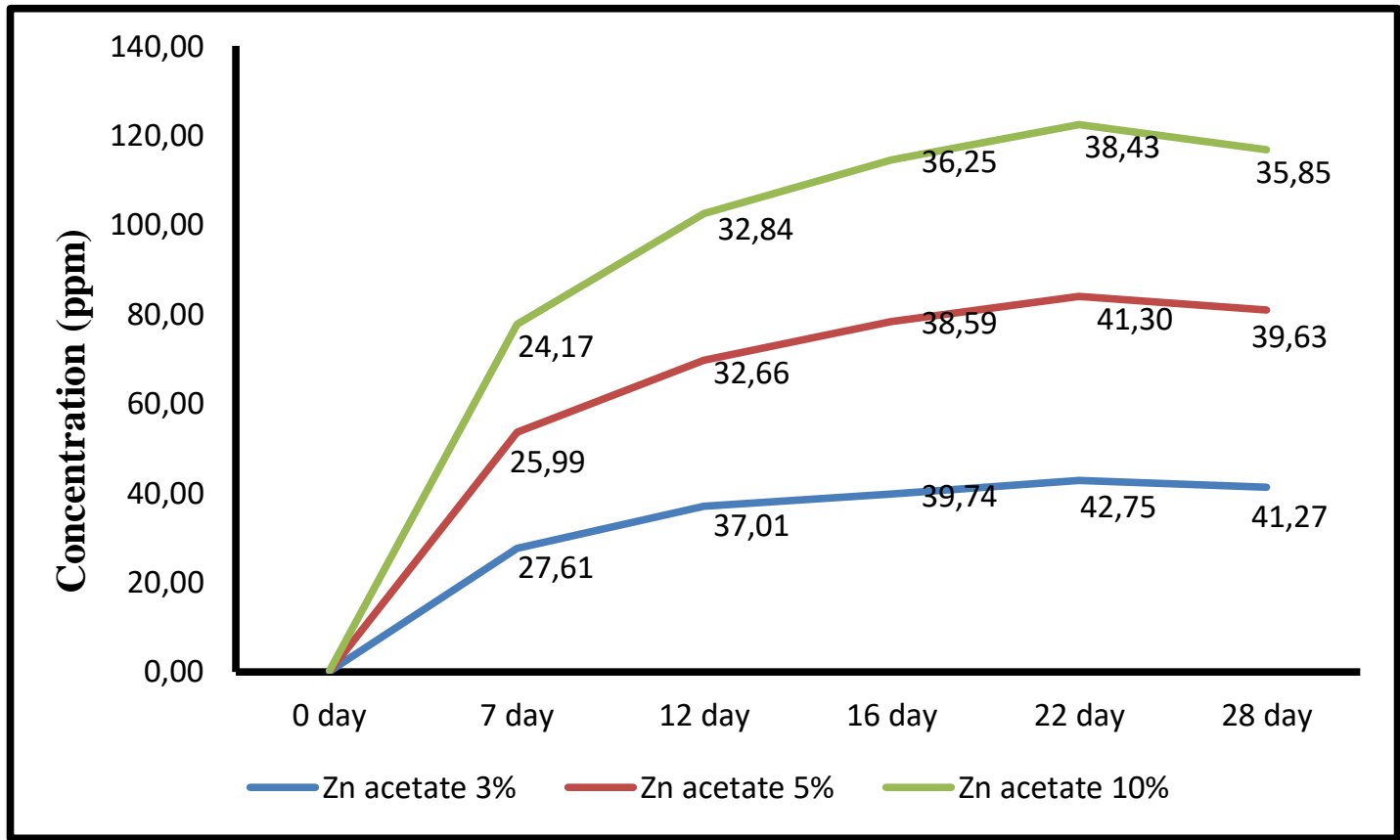

Figure 9. Test of beads activity on Methylene blue adsorption 